\title{
Postural Structure and Mechanic Syndromes Associated with Human Movement Physiology: A Traditional Review of Re-modelling Musculature
}

\author{
Postür Kas Iskelet ve Mekanik Sendromlar ile ilgili Insan Hareket Fizyolojisi: Kas Iskelet \\ Remodellemesi Geleneksel Derleme
}

\section{Abstract}

Postural musculature functioning emphasises the importance of dynamic actions in multiple motion stresses and the mechanical deficiencies of movement modelling. Human posture is a result of the distortion of space in different increments in static and dynamic conditions. Postural dysfunctions are caused by muscle tightness related to myofascicular stiffness. Herein, this traditional review explains the heat- and pain-induced syndromes, general mechanical deficiencies in muscle performance, and hypertrophy. Postural analysis shows the connection of motion system to biomechanics and kinesiology. Mechanical syndromes are caused by complex crossovers in the postural skeleton. Complex postural muscles confirm isometric modelling for limb fixation according to the location of compartment. However, different movement patterns in individualised exercises are inadequate and require further comparisons. Therefore, kinematic data regarding mechanical syndromes are limited. Moreover, this study shows how muscular performance should be involved in postural exercises. Postural muscle strength is the conditioning of the muscles in different working principles. Postural muscle dysfunctions should be analysed to compare atrophic characteristics. Current approaches present that postural analyses should be individualised to examine atrophic shortening and elongation because individuals have varied resistance and motion performance. This study aimed to explain development of mechanical syndromes to evaluate the indexes before postural exercises. These mechanical syndromes are presented in view of the longitudinal body kinesiology involved in comprehensive exercises.

Keywords: Postural musculature, mechanical syndromes, movement modelling

\section{Öz}

Postür kas performans modellemede çoklu hareket streslerin mekanik eylemlerine önem vurgular. İnsan duruşu, statik ve dinamik boyutlarda farklı artışlarla uzay konumlandırmalarıdır. Postür fonksiyonların nedeni, miyofasiküler sertliğe bağlı kas-iskelet sistemindeki gerginliktir. Çalışma geleneksel bir derlemedir. Performans ise genel mekanik eksikliklerin hipertrofi olduğu ısı ve ağrı kaynaklı sendromları açıklamaktadır. Postür analizi, biyomekanik ve kinesiyolojik nedenlere bağlı hareket sisteminde gösterilir. Mekanik sendromlar, postüral iskeletteki karmaşık ve geçitler ile ortaya çıkar. Karmaşık postüral kaslar, kompartıman yerleşimlerine göre uzuv fiksasyonu için izometrik modellemeyi doğrular. Bu nedenle kinematik veriler, sendromları göstermede sınılıdır. Ek olarak, çalışma, kas performansının postüral egzersizlere nasıl dahil edilmesi gerektiğini göstermektedir. Mevcut yaklaşımlar, postüral analizlerin atrofik kısalma ve uzama için bireysel olması gerektiğini söylüyor. Çünkü bireylerin hareket performans faktörlerine karşı direnci değişkendir. Çalışmanın amacı postüral egzersizlerden önce indeksleri değerlendirmek için mekanikte sendromların oluşumunu açıklamaktır. Bu çalışmada, kapsamlı egzersizde yer alan boylamsal vücut kinesiyolojisi temelinde mekanik sendromlar gösterilmiştir.

Anahtar kelimeler: Postüral kas sistemi, mekanik sendromlar, hareket modellemesi

Address for Correspondence/Yazışma Adresi: Yeliz Kahraman Ph.D. Student, Akdeniz University Institute of Health Sciences, Department of Movement and Training, Antalya, Turkey

Phone: +90 5428227162 E-mail: yelizkahramana@hotmail.com ORCID ID: orcid.org/0000-0001-8209-4087 Received/Geliș Tarihi: 06.05.2021 Accepted/Kabul Tarihi: 22.06.2021 


\section{Introduction}

Postural muscle ability sees exercise and movement patterns as the formation of syndromes in limited areas for the changes seen in overactive and lower active muscle groups, together with asymmetries in the kinetic chain sequences of the body involved in static and dynamic movement posture. Loss of muscle function can be strengthened by the atrophic effect (1). Strength training increases the size of the anatomy and physiological muscle mass causing movement deficiencies on the basis of serious medical science (2). The functional ability of the muscle depends on the shape of the muscle mass during movement, the mechanical properties of the tendon tissues. Strength training has increased anatomical muscle strength and neuromuscular locomotive posture for not less than 16 weeks. The increased number of sarcomeres due to the fibril strain, which can be shown by the fascicle length in fibril increase, causes hypertrophy as a force dynamics in series and parallel $(3,4)$. In contrast, physical stresses of the leg limb in the musculoskeletal system in the postural muscles movement access (5). Abnormal injuries other than normal posture showed posture syndrome behaviors in runners, handball, hockey, baseball, and volleyball players as a result of loss of mechanical properties of wrong walking foot pronation (6). Therefore, the beginning of technical exercises, muscle-tendon and joints, which are successful muscular models (7). In the vertical jump movement phase, the volleyball player stepping and using the counter height in accessing the ball or in high pass shots is the technical representation of the walking phases (8). The basic muscle function is therefore the heel against ground reactions in the walking cycle of the lower limb of the lumbopelvic-hip complex in the skeletal system. Medial stress syndrome, which shows foot pronation according to the shock absorption of strokes (9), is important in maintaining postural stabilization of the upper segments in changing reactions and rotations (10). Individual walking is a good examination method in unnatural behaviors. The evaluations should be downward with treadmill and walking in the opposite direction at a distance of 6 meters, especially for individuals with complaints of musculoskeletal pain under 25 years of age, 3-12 months. The loss of energy in the tibialis posterior muscles located at 50-60\% increased fasiculations of the central nervous system in strength cause postural muscle disorders (11); electrophysiological nerve stimulation in myotonic muscle tone, especially in muscle activation and relaxation so-called Duch syndrome has shown by podiatrics, sport therapist and physiotherapists (12). In fact, asymmetric complexes on one side of the body have shown the loss of muscular hypertrophy in the leg, strength at extremely small distances, and postural deficiencies that may result in strength and flexibility in physical individuals dealing with weightbearing sports (13). When complex muscles appear atrophic, especially triple-headed gastrocne. The soleus and deep tendon plantaris in the same location of the minus, pain in the knee joint as a result of pressure on the leverage force is the reason for the lumbopelvic-hip complex syndrome $(14,15)$. The cross muscles that will form the mechanics of the postural musculoskeletal is under the effect of foot pressures, except for the upper-lower part. Knee-tendon disorder separated from the lumbopelvic hip complex is posterior tibial and medial stress syndromes (16), the syndrome seen on the tenderness of upper limb compartment muscles is an upper cross syndrome (17). Conclusion, general populations studies different showing on postural deviation as postural musculature syndrome for example, head and ankle plumbline (Table 1).

\section{Knee Tendon Disorders, Lumbo-Pelvic-Hip Complex Syndrome}

Deformities and pains in the knee tendon structure are seen in the iliotibial band in cases of abnormal deviation of pelvic asymmetric and inclination changes, unilateral muscle elongation, and muscle shortness of overloads (16). In athletes, shortening and looseness in the lower extremity joint muscles as shoulder, pelvic, lumbar region in severe potential energy loss it causes the known core region or lumbopelvic-hip complex $(17,18)$. Anterior knee pain patella femoral syndrome volleyball and basketball etc. In sports branches, jumping, running and complex movements such as the squat, deadlift, back squat, etc. As a result of the reduction of the anterior Hoffa swelling of the knee, it has been observed more frequently as a result of the reduction of the swelling of the anterior half of the knee. In this case, the ankle is directly affected by the ground reaction force and the foot pronation rotation in runners brought medial stress syndrome. In addition, fibularis and peroneal muscles pronation-elevation force $\left(10-15^{\circ}\right)$ gastrocnemious vertical power deficiency at an angle $(19,20)$. Exercise models bring along mechanical deficiencies in very different formations as can be seen. The reasons for exercising or not exercising were suggested for the general population in the postural analysis strategy for the evaluation of body weight, body mass index, waist-hip ratio, leg length difference, longitudinal alignment of the medial arch of the foot, and as a result (20), m. quadricepshamstring the change in the vascular muscle tone in the fixation of the quadriceps-hamstring flexibility can also cause the neuromuscular repetitive isotonic tendon dynamics changes

\begin{tabular}{|l|l|}
$\begin{array}{l}\text { Table 1. Leg length of postural body segments cause } \\
\text { specific 2-6 } \text { m walking }\end{array}$ \\
$\begin{array}{l}\text { Postural body } \\
\text { segments }\end{array}$ & $\begin{array}{l}\text { Limitation causing postural } \\
\text { walking }\end{array}$ \\
\hline $\begin{array}{l}\text { Shoulder } \\
\text { (first segment) }\end{array}$ & One-sided shoulder drop \\
\hline Humerus & One side arm swing abduction \\
\hline $\begin{array}{l}\text { Pelvic } \\
\text { (middle segment) }\end{array}$ & One side low in swing \\
\hline Leg & One side rotation \\
\hline Patella & One-sided hyperextension \\
\hline Foot (last segment) & Foot turned lateral \\
\hline & \\
\hline
\end{tabular}


in the anterior compartment, causing Hoffa swelling in the knee, and the knee rotation restriction is seen in the chronic complex in microscopic fibril degeneration $(19,20)$. The knee experiences load change with pressure against movement while in hyperextension patella femoral joint syndrome is a serious problem (21).

\section{Lumbo-Pelvic-Hip Complex, Posterior Cross Syndrome}

Lumbopelvic hip complex in muscles adhering to the extreme anterior pelvic tilt joint of the pelvic cross syndrome directed to deformity, which is usually shown in phase $1 ; \mathrm{m}$. gluteus maximus, medius, iliopsoas, rectus abdominis, posterior tibialis shortenings and the energy of the upper compartment (22). As the muscles show limb location in complex fixation, the longitudinal slope of the femur, hip, pelvic and lumbar spine, known as the core region, also affects the spinal stability and causes advanced lower cross syndrome such as lumbar lordosis (23-25). When postural analysis evaluations determine the factors that cause the treatment, first of all, knee pain should create a perception of pain on the pelvic stability and flexibility of the hip flexor muscles $(22,26)$. In the whole lumbar region where pain threshold does not occur, warm muscle temperature should be created and exercise stability should be applied to touch or spinal cord sensitivity. In this case, for postural control, there are movements such as isometric arm shoulder flexion, prone trunk extension, superman, bird dog movements in which the upper limbs will continue at eye level in a position against gravity, and balance exercises tend towards mechanics in the contraction modes $(23,24)$. It was necessary to provide ligament tension, which is important in mechanical movements, and to balance the force pressures in the spinal discs against gravity in the body weight. Therefore, corrective exercises in postural muscles are suitable methods in athletic physical development for minimal energy expenditure. Posture analysis formation, as can be obtained from previous information, should be evaluated in the evaluation of shoulder, pelvic and spinal inclination deviations in rapid visual asymmetry in neuro-musculoskeletal weaknesses (26). As explained earlier, foot pressure changes in the Olympic athletes, pes planus, leg length changes were obtained in the gait analysis where the evaluation of foot posture did not allow muscle function in terms of degrees of the muscle in the range of motion (27). The change in foot pressures in the lower limb is the cause of the cross-vertical shortening of the anterior-posterior tibialis, soleus and flexor digitorum longus muscles in one example, the basic muscles of pelvic rotation into soleus and sartorious in basketball players. Since the motor activation of the sartorius does not compensate for the mechanical temperature change, the increase in the hip range of motion in the leg lengths and the involvement in negative motion caused the lumbo-pelvic-hip complex to be observed in 1-3 phases (26). Various limitations and syndromes caused by muscles in body segments including general postural gait have been syndromes that can be shown in the head, shoulder, middle pelvic and foot posture indexes in the lower and upper crossover (28).

The limitations of showing postural whole body segments within walking are explained. However, since postural mechanical movements show the occurrence of different syndromes only in general body limbs, syndromes should be seen as problems that occur before and after (28). Observing such muscular limitations in body segments magnetic resonance imaging, ultrasound, and C-tomography are methods that can show eccentric degrees in the extension of motion of joint torque dynamics for dynamic posture (29). The methods have been used in the disruption of the potential loss of strength of muscle groups and geriatric syndromes for soft tissues under dynamic movement conditions of the muscle. Therefore, due to the fact that the center of the postural musculature is in the bone location of the lower and upper limbs, for example; in the example of cycling in the leg area where muscle power is used in fasciculation, the pressure location in dynamic conditions is not shown in the hip-pelvic complex as assessed in the right-left lower limb (30). However, foot, medial, and tibial stresses should be included in exercise patterns that will maintain muscle balance in the lower compartment and upper compartment of the shoulder, head, scapula. In this approach, postural insufficiencies in exercise and sports groups, shortness of the lever muscles that make up the movements, immobilization of the tension, weakness are the reasons for the lack of force against long-term resistance loads (31). Moreover, it is difficult to plan exercise models for syndromes.

\section{Shoulder Cross Syndrome}

It causes multiple neck pain, such as axial, due to the increase in degree intervals in the arm and cervical muscles along the acromioclavicular and glenohumeral joints in the upper shoulder compartment (25). The shoulder posture is revealed in isometric muscle modeling of myofascial and tendon tensions in the posterior muscles (32). Loss of function in the shoulder, which causes more shoulder protraction and irregular localization in shoulder stability, with the glenoid fossa tension on the head of the arm and superior anterior shoulder capsule connection, $\mathrm{m}$. supraspinatus from the weakness of the deltoid posterior fibrils (33). Over time, unbalanced muscle shortness, collision syndromes and functional loss of rotator cuff muscles have been caused. In athletes, the shoulder muscles are more effective in the movements of the deep muscles in the cervical region that cause loss of stability function, usually in the shoulder and arm elevation and abduction intervals, at different kinematic movement phases. Since cervical tensions cause the neck muscles to be used under excessive stress, shoulder cross syndrome indicates the posterior junction syndrome that forms the shoulder junction $(34,35)$. Deep cervicals cause advanced head posture and myofascicular separation due to shoulder and upper cervical hyperextension $(32,36,37)$. 
The dynamics in the structure of motion of the shoulder posterior cross syndrome joint are shown (Table 2).

\section{Pelvic Crossed Syndrome}

Pelvic asymmetry kinematic gluteus medius muscle weakness resulting in anterior pelvic tilt increase in the range of motion, pelvic cross syndrome in the upper group lumbar region (38). Pelvic syndrome causes the weight balance in the central region in the rectus abdomen balance. However, in the anterior compartment muscles, where the hamstring muscle will vary in excessive of motion, especially the sartorius and vastus medial, the excessive pressure changes put an excessive stress load on the upper compartment vertical discs due to the weakening of the pelvic gluteal muscles (39). This situation is mostly in the fasciculation of the L5/S1 spinals, the large compartment in the pelvic region; the gluteus muscles and the iliopsoas cause myofascular weakness (40). This weakness is the result of sacroiliac joint disorders resulting from rotation change, which is seen as lumbopelvic pain when the posterior pelvic muscles are separated from the tensor fascia lata and sartorius hip flexors while the overactive lumbar muscle is flexed (38). As a result of the separation in the lateral compartment since hip flexors cannot show pelvic and hip contraction against isometric movements after a while, the vertical muscle longitudinal anterior superior iliac sacrum causes disruption in resistance exercises $(38,40,41)$. Therefore, pelvic cross-posterior syndrome has revealed low back problems associated with walking and leg changes $(39,42,43)$. Posterior postural examinations should confirm middle-cross syndrome of pelvic muscle groups in different functional tasks. Postural insufficiency and problems seen as a result of the change in muscle shortness and weakness that cause postural pelvic cross syndrome (Table 3).
Horizontal transition of the pelvic slope over the lumbar spine junction $\mathrm{m}$. quadratus lumborum atrophy is a moderate pelvic cross syndrome in the poas muscle L1-L5 spinal cord accompanied by severe atrophic loss in muscle weakness in the middle region (44). The intensity of flexion in the pelvic lower compartment $\mathrm{m}$. gastrocnemius and $\mathrm{m}$. soleus. In other words, the lateral and posterior fossae affect the length change in these muscles mechanically in gait pressure $(44,45)$. Similarly, patelle is the cause of femoral pain $(44,46-48)$.

\section{Postural Upper Cross and Lower Cross Syndrome}

Postural insufficiencies are a serious problem especially in individuals participating in maximal muscle strength and strength training on the upper and lower cross syndrome, which includes acute and chronic syndromes that differ from the middle-compartment lumbo-pelvic-hip complex as the muscular activity of the musculoskeletal structure (18). Most of the postural insufficiencies observed in athlete groups (44). However, overactive movement patterns show strength value in weakening muscles involved in the same movement (46). Thus, the energy in postural muscular activities, which is further evaluation, is eccentric (46). Overactive muscle strength or less active muscle strength, upper cross syndrome, and lower cross syndrome limitation within the whole body structure (47). The limitation is the forward head-rounded shoulder- and cervical kyphosis arising from the lumbo-pelvic-hip complex in which exercise is inhibited (45-47). Postural exercises prevent such syndromes as well as correct them. Separating, complex and comprehensive muscle activation corrective exercises (46). Kinetic muscle imbalance in different sports branches, lower cross syndrome, forward posture in increased pelvic forward

Table 2. Shoulder posterior syndrome postural analysis

\begin{tabular}{|l|l|l|}
\hline Muscle imbalance & Weakened muscles & Postural evaluation characteristic \\
\hline Shortened muscles & Low shoulder junction fixators: & Shoulder elevation \\
\hline Shoulder-upper junction fixators: & Middle trapezius & \\
\hline Upper trapezius & Lower trapezius & \\
\hline Levator scapula & Rhomboid & \\
\hline Scalenes & Serratus anterior & Shoulder protraction \\
\hline Shoulder junction & Shoulder junction retractors: & \\
\hline Protractors: & Rhomboid & \\
\hline Pectoralis major & Middle trapezius & Forward head posture \\
\hline Pectoralis minor & Lower trapezius & Increased cervical lordosis \\
\hline & Deep neck flexors: & Upper cervical hyperextension \\
\hline Neck extensors: & Longus colli & Cervico-thoracic kyphosis \\
\hline Short neck extensors & Longus cervicus & \\
\hline Sternocleidomastoid & Longus capitis & \\
\hline Upper trapezius & & \\
\hline Levator scapula & &
\end{tabular}


inclination, the reason for the forward head posture due to cervical hyperextension in the upper compartment is that the limb strength regulates the trunk changes $(48,49)$. Postural injuries in the limb localization of the lower extremity overactive muscles; gastrocnemious, soleus, hip deep adductors, tensor fascia latea, gluteus medius, superficial latissimus dorsi, and thoracolumbar fascia involved in the minimus complex and muscles weakened by less active extension; anterior, posterior tibialis, gluteus maximus, gluteus medius, transfer abdominis, internal oblique cross syndrome $(49,50)$. Upper cervical spine C4-7, previously known as a proximal cross syndrome by Lee, was the ability to move the scapula in the upper thorax and shoulder girdle $(50,51)$. Later, dynamic force models were seen as a problem of forward head and cervicothoracic kyphosis of the fascicular tendon tension, which causes cervical hyperextension as a result of the extensive pressure of shear force on the cervical muscles $(52,53)$. Therefore, the tension deformity is seen as the central nerve activity in mechanomyographic protein transitions for optimal muscle performance and movement during energy transitions affected the shoulder posture $(52,53)$.

Vladimir Janda (1923-2002) muscle groups shortened in the upper compartment; in deep muscles, the movements of which are elongated and shortened for the muscular function in which the upper trapezius, levator scapula, sternocleidomastoid, scalenes, latissimus dorsi, teres major, subscapularis and pectoral muscules affect scapular dyskinesia; deep cervical flexors-longus colli, cervicis, capitis, serratus anterior, rhomboid, middle trapezius, lower trapezius, teres minor, and infraspinatus motor unit firing rate reductions and shows negative movement function in the cervicothoracic region $(32,45,48,49)$. This appearance causes a lower shoulder in the future, increased kyphosis head posture as well as cervical lordosis deformity (26-28). If the postural muscles are not technically placed even with proper fixation, overloading negatively affects the postural skeleton. The studied view confirms that fitness components in load planning by grading the development of muscle shortness and tensile stress, which are overlooked for the comprehensive muscle rotation balance, $<4-12$ weeks long (30 seconds rest) and >8-12 weeks (90s rest), exercise programs are postural in single-joint muscules. Maximum voluntary contractions for muscle development at optimal accuracy of $30-50 \%$ (set loading 10-12 repetitions), between $70-90 \%$ of maximal voluntary contractions if for multiple joint muscle groups, and $80-95 \%$ in athletes depending on general movement speed 8-10. It is deemed necessary to create repetitions (51-53).

Thus, the highest quality neuromuscular exercise patterns will be able to test versatile performance, technical accuracy muscular ability, biomechanical and neurological practice. Therefore, periodic advancing therapists recommend extensive exercises in the loss of strength against the compartments in the kinetic chain $(53,54)$. The movement of postural in dynamic actions must achieve tendon dynamics or tendon torque development, which are components of muscular ability and fitness in sports branches in structural micro, meso, and macro planning. Fascicular changes are directed to all body parts in isometric contraction strength (52-54). In the example of the structure of parallel muscle groups in the skeletal muscular system kinetic structure under stress conditions; multiple joint movements in swimmers, integrative isometric contraction occurs for regional muscle strength in the upper compartment (54-56). Therefore, multiple joint movements in physical individuals without exercise injury are integrative, while single and multiple joint levers for regional muscle strength in athletic groups are inclusive in dynamic contraction modes (56-59). Postural neuromuscular increases thus confirm the neuromuscular increases. On the other hand, there is a choice of electrophysiological muscle activation to protect muscle, tendons, ligaments, and joints for fat loss to compliment the body balance on double exercise days (54-56). Electrophysiology, motor unit synchronization of mechanical temperature changes, helps to reduce stress tension by assistants such as foam roll and exercise types can be changes. Therefore, the transition from low intensity to high intensity in athletes after high intensity, 4-6 weeks long program and 2-4 days per week in non-exercising groups (57-59). On this basis, all resistance exercises that allow movement biomechanics are preconditioned for the determination and treatment of postural syndromes can take place.

\section{Table 3. Pelvic posterior crossed syndrome}

\begin{tabular}{|l|l|l|}
\hline Postural muscle shortness & Postural muscle weakness & Postural problems \\
\hline Hip flexors: & Hip extensors: & \\
\hline $\begin{array}{l}\text {-lliopsoas } \\
\text {-Rectus femoris }\end{array}$ & -Gluteus maximus & $\begin{array}{l}\text { Lumbar lordosis } \\
\text { ASIS }\end{array}$ \\
\hline Lumbar extensors: & Lumbar flexors: & \\
\hline -Lumbar spin fascia & -Rectus femoris & Protuberant convex abdomen \\
\hline The dominant hip abductor: & Hip adductors: & \\
\hline -Tensor fascia lata & -Gluteus medius & Uneffected iliac crest \\
\hline Pelvic elevator: & -Gluteus minimus & \\
\hline -Quadratus lumborum & & Lateral pelvic tilt \\
\hline ASIS: Anterior superior iliac sacrum & & \\
\hline
\end{tabular}


Complementary validations that prevent grading of movement techniques in total coordination and corrective are ability of the bone leverage dynamics in the fixation of multiple joints relative to single joints (56-58). Corrective exercise changes including of body parts, such as dynamic squat and deadlift and back squat movements, such as hip, knee, foot and soles pressure and mechanical tendon development that would allow leverage Dynamics $(59,60)$. Accordingly, it will be more accurate to create total stress power in the mechanics of active and passive muscle groups according to postural segments in sports branches and exercises (53-57). Mechanical syndromes, pediatric physiotherapists and sports therapists are work generally in geriatric anatomy and physiology suggest human structure limitations of dynamic body segments. Syndromes show very complex in postural insufficiencies and should be explain upper and lower compartment syndromes, the importance of mechanical movements should be emphasized, and at the same time, it is appropriate to show the tendency to the optimal degrees of the muscle in the insufficient population that can create stress in practice.

\section{Ethic}

Peer-review: Externally peer-reviewed.

Financial Disclosure: The author declared that this study has received no financial support.

\section{References}

1. Kahraman Y. Spor \& Postural Bozukluklar Bölüm-17. Sporun Kavramsal Temelleri-5. 2020. p. 317-32.

2. Wilson GJ, Murphy AJ, Walshe A. The specificity of strength training: the effect of posture. Eur J Appl Physiol Occup Physiol 1996;73:346-52

3. Azizi E, Brainerd EL. Architectural gear ratio and muscle fiber strain homogeneity in segmented musculature. J Exp Zool A Ecol Genet Physiol 2007;307:145-55.

4. Schoenfeld BJ. The mechanisms of muscle hypertrophy and their application to resistance training. J Strength Cond Res 2010;24:2857-72.

5. Holden S, Boreham C, Doherty C, Wang D, Delahunt E. Dynamic postural stability in young adolescent male and female athletes. Pediatr Phys Ther 2014;26:447-52.

6. Martínez-Nova A, Gómez-Blázquez E, Escamilla-Martínez E, PérezSoriano P, Gijon-Nogueron G, Fernández-Seguín LM. The foot posture index in men practicing three sports different in their biomechanical gestures. J Am Podiatr Med Assoc 2014;104:154-8.

7. Shelburne KB, Torry MR, Pandy MG. Muscle, ligament, and jointcontact forces at the knee during walking. Med Sci Sports Exerc 2005;37:1948-56

8. Ozawa Y, Uchiyama S, Ogawara K, Kanosue K, Yamada H Biomechanical analysis of volleyball overhead pass. Sports Biomech 2019:1-14.

9. Noh B. Running characteristics of plantar flexor forces based on different foot strike patterns in medial tibial stress syndrome. Asian J Kinesiol 2020;22:48-54.

10. Shih YF, Wang YC. Spiking Kinematics in Volleyball Players With Shoulder Pain. J Athl Train 2019;54:90-8.

11. Sponbeck JK, Frandsen CR, Ridge ST, Swanson DA, Swanson DC, Johnson AW. Leg muscle cross-sectional area measured by ultrasound is highly correlated with MRI. I Foot Ankle Res 2021;14:5.
12. Kronlage C, Grimm A, Romano A, Stahl JH, Martin P, Winter N, et al. Muscle Ultrasound Shear Wave Elastography as a Non-Invasive Biomarker in Myotonia. Diagnostics (Basel) 2021;11:163.

13. Reggiani C, Schiaffino S. Muscle hypertrophy and muscle strength: dependent or independent variables? A provocative review. Eur J Transl Myol 2020;30:9311.

14. Ishii T, Kawagishi K, Hayashi S, Yamada S, Yoshioka H, Matsuno Y, et al. A bilateral third head of the gastrocnemius which is morphologically similar to the plantaris. Surg Radiol Anat 2021 Jan 10.

15. Kahraman Y. Corrective isometric strength in lumbopelvic-hip complex for postural structure muscle formation. IJSPR 2021;79:1-

16. Becker J, Nakajima M, Wu WFW. Factors Contributing to Medial Tibial Stress Syndrome in Runners: A Prospective Study. Med Sci Sports Exerc 2018; 50:2092-100.

17. Mubeen I, Komboh SM, Akhtar W, Gondal J, Iqbal M, Wattoo A, et al. Prevalence of upper cross syndrome among the medical students of university of lahore. Int J Physiother 2016;3:381-4.

18. Martín-San Agustín R, Benítez-Martínez JC, Medina-Mirapeix F, Casaña-Granell J. Sex Differences and Patterns of Muscle Stiffness in the Knee Flexor and Extensor Musculature Through Analysis of Isolated Bellies. J Strength Cond Res 2021;35:1044-9.

19. Rio E, Kidgell D, Purdam C, Gaida J, Moseley GL, Pearce AJ, et al. Isometric exercise induces analgesia and reduces inhibition in patellar tendinopathy. Br J Sports Med 2015;49:1277-83.

20. Kapo S, Rađo I, Smajlović N, Kovač S, Talović M, Doder I, et al. Increasing Postural Deformity Trends and Body Mass Index Analysis in School-age Children. Zdr Varst 2018;57:25-32.

21. Kongsgaard M, Qvortrup K, Larsen J, Aagaard P, Doessing S, Hansen $P$, et al. Fibril morphology and tendon mechanical properties in patellar tendinopathy: effects of heavy slow resistance training. Am J Sports Med 2010;38:749-56

22. Wasserberger KW, Downs JL, Barfield JW, Williams TK, Oliver GD. Lumbopelvic-Hip Complex and Scapular Stabilizing Muscle Activations During Full-Body Exercises With and Without Resistance Bands. J Strength Cond Res 2020;34:2840-8.

23. Kelly $M$, Jacobs $D$, Wooten ME, Edeer AO. Comparison of electromyographic activities of lumbar iliocostalis and lumbar multifidus muscles during stabilization exercises in prone, quadruped, and sitting positions. J Phys Ther Sci 2016;28:2950-4.

24. Dafkou K, Kellis E, Ellinoudis A, Sahinis C. Lumbar Multifidus Muscle Thickness During Graded Quadruped and Prone Exercises. Int J Exerc Sci 2021;14:101-12.

25. Shah J, Tanwar T, Iram I, Aldabbas M, Veqar Z. Effect of Increased Lumbar Lordosis on Lumbar Multifidus and Longissimus Thoracis Activation During Quadruped Exercise in Patients With Chronic Low Back Pain: An EMG Study. J Appl Biomech 2020:1-8.

26. Ludwig O, Kelm J, Hammes A, Schmitt E, Fröhlich M. Targeted Athletic Training Improves the Neuromuscular Performance in Terms of Body Posture From Adolescence to Adulthood - LongTerm Study Over 6 Years. Front Physiol 2018;9:1620.

27. Gimunová $M$, Válková $H$, Kalina $T$, Vodička T. The relationship between body composition and foot posture index in Special Olympics athletes. Acta Bioeng Biomech 2019;21:47-52.

28. Winter DA. Human balance and posture control during standing and walking. Gait \& Posture 1995;3:193-214.

29. Perkisas S, Bastijns S, Baudry S, Bauer J, Beaudart C, Beckwée D, et al. Application of ultrasound for muscle assessment in sarcopenia: 2020 SARCUS update. Eur Geriatr Med 2021:12:45-59.

30. Austin N, Nilwik R, Herzog W. In vivo operational fascicle lengths of vastus lateralis during sub-maximal and maximal cycling. J Biomech 2010;43:2394-9.

31. Maden-Wilkinson TM, Balshaw TG, Massey GJ, Folland JP. What makes long-term resistance-trained individuals so strong? A comparison of skeletal muscle morphology, architecture, and joint mechanics. J Appl Physiol (1985) 2020;128:1000-11.

32. Alenabi T, Whittaker RL, Kim SY, Dickerson CR. Arm posture influences on regional supraspinatus and infraspinatus activation in isometric arm elevation efforts. J Electromyogr Kinesiol 2019:44:108-16. 
33. Hawkes DH, Khaiyat OA, Howard AJ, Kemp GJ, Frostick SP. Patterns of muscle coordination during dynamic glenohumeral joint elevation: An EMG study. PLoS One 2019;14:e0211800.

34. Lee HM. Rehabilitation of the proximal crossed syndrome in an elderly blind patient: a case report. J Can Chiropr Assoc 2000;44:223-9.

35. Bordelon NM, Wasserberger KW, Cassidy MM, Oliver GD. The Effects of Load Magnitude and Carry Position on LumbopelvicHip Complex and Scapular Stabilizer Muscle Activation During Unilateral Dumbbell Carries. J Strength Cond Res 2021;35(Suppl 1):S114-S9.

36. Subbarayalu AV, Ameer MA. Relationships among head posture, pain intensity, disability and deep cervical flexor muscle performance in subjects with postural neck pain. J Taibah Univ Med Sci 2017;12:541-7.

37. Sun A, Yeo HG, Kim TU, Hyun JK, Kim JY. Radiologic assessment of forward head posture and its relation to myofascial pain syndrome. Ann Rehabil Med 2014;38:821-6.

38. Laird RA, Keating JL, Kent P. Subgroups of lumbo-pelvic flexion kinematics are present in people with and without persistent low back pain. BMC Musculoskelet Disord 2018;19:309.

39. Kim SH, Kwon OY, Yi CH, Cynn HS, Ha SM, Park KN. Lumbopelvic motion during seated hip flexion in subjects with low-back pain accompanying limited hip flexion. Eur Spine J 2014;23:142-8.

40. Bosch U, Tscherne $H$. The pelvic compartment syndrome. Arch Orthop Trauma Surg 1992;111:314-7.

41. Flores-León A PT, MSc, Redenz G PT, Valencia OD PT, GuzmánVenegas R PT, MSc, Araneda OF MD, PhD, Berral de la Rosa F MD, PhD. Coordination of the rotational movement of the pelvis and the hip in men without low back pain, with control impairment of the lumbopelvic region in the sagittal plane. Physiother Theory Pract 2020;36:810-7.

42. Oleksy L, Bylina D, Mika A, Sołtan J, Kielnar R. The relationship between lumbo-pelvic-hip complex and knee joint dysfunctions. J Nov Physiother 2018;8:e149.

43. Cibulka MT, Sinacore DR, Cromer GS, Delitto A. Unilateral hip rotation range of motion asymmetry in patients with sacroiliac joint regional pain. Spine (Phila Pa 1976) 1998;23:1009-15.

44. Key J. The pelvic crossed syndromes: a reflection of imbalanced function in the myofascial envelope; a further exploration of Janda's work. J Bodyw Mov Ther 2010;14:299-301.

45. Bordoni B, Varacallo M. Anatomy, Bony Pelvis and Lower Limb, Gastrocnemius Muscle. StatPearls(internet) February 7, 2021.

46. Hoshikawa K, Yuri T, Giambini H, Kiyoshige Y. Shoulder scaption is dependent on the behavior of the different partitions of the infraspinatus muscle. Surg Radiol Anat 202;43:6153-9.

47. Seidi F, Bayattork M, Minoonejad H, Andersen LL, Page P. Comprehensive corrective exercise program improves alignment, muscle activation and movement pattern of men with upper crossed syndrome: randomized controlled trial. Sci Rep 2020;10:20688
48. Gillani SN, Ain Q, Rehman SU, Masood T. Effects of eccentric muscle energy technique versus static stretching exercises in the management of cervical dysfunction in upper cross syndrome: a randomized control trial. J Pak Med Assoc 2020;70:394-8.

49. Clifford AM, Dillon S, Hartigan K, O'Leary H, Constantinou M. The effects of McConnell patellofemoral joint and tibial internal rotation limitation taping techniques in people with Patellofemoral pain syndrome. Gait Posture 2020;82:266-72.

50. Chaudhari AMW, VAN Horn MR, Monfort SM, Pan X, OÑate JA, Best TM. Reducing Core Stability Influences Lower Extremity Biomechanics in Novice Runners. Med Sci Sports Exerc 2020;52:1347-53

51. Bae WS, Lee HO, Shin JW, Lee KC. The effect of middle and lower trapezius strength exercises and levator scapulae and upper trapezius stretching exercises in upper crossed syndrome. J Phys Ther Sci 2016;28:1636-9.

52. Hrysomallis C. Effectiveness of strengthening and stretching exercises for the postural correction of abducted scapulae: a review. J Strength Cond Res 2010;24:567-74.

53. Arshadi R, Ghasemi GA, Samadi H. Effects of an 8-week selective corrective exercises program on electromyography activity of scapular and neck muscles in persons with upper crossed syndrome: Randomized controlled trial. Phys Ther Sport 2019;37:113-9.

54. Bayattork M, Seidi F, Minoonejad H, Andersen LL, Page P. The effectiveness of a comprehensive corrective exercises program and subsequent detraining on alignment, muscle activation, and movement pattern in men with upper crossed syndrome: protocol for a parallel-group randomized controlled trial. Trials 2020;21:255.

55. Altamirano KM, Coburn JW, Brown LE, Judelson DA. Effects of warm-up on peak torque, rate of torque development, and electromyographic and mechanomyographic signals. J Strength Cond Res 2012;26:1296-301.

56. Karimian R, Rahnama N, Ghasemi G, Lenjannejadian S. Photogrammetric Analysis of Upper Cross Syndrome among Teachers and the Effects of National Academy of Sports Medicine Exercises with Ergonomic Intervention on the Syndrome. J Res Health Sci 2019;19:e00450.

57. Frydendal T, Eshøj H, Liaghat B, Edouard P, Søgaard K, JuulKristensen B. Sensorimotor control and neuromuscular activity of the shoulder in adolescent competitive swimmers with generalized joint hypermobility. Gait Posture 2018;63:221-7.

58. Mann SJ, Lam JC, Singh P. McKenzie Back Exercises. 2021; In: StatPearls [Internet]. Treasure Island (FL): StatPearls Publishing; 2021.

59. Kim SY, Weon JH, Jung DY, Oh JS. Effect of the scapula-setting exercise on acromio-humeral distance and scapula muscle activity in patients with subacromial impingement syndrome. Phys Ther Sport 2019;37:99-104

60. Vinstrup J, Sundstrup E, Brandt M, Jakobsen MD, Calatayud J, Andersen LL. Core Muscle Activity, Exercise Preference, and Perceived Exertion during Core Exercise with Elastic Resistance versus Machine. Scientifica (Cairo) 2015;2015:403068. 